\section{E- LOGOS}

ELECTRONIC JOURNAL FOR PHILOSOPHY ISSN 1211-0442

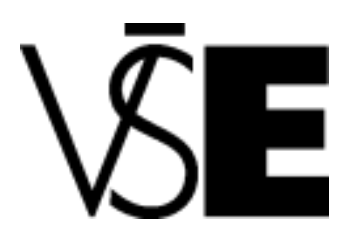

University of Economics

Prague

\title{
Political Reluctance: On the Noble Lie in Plato's Republic
}

Olof Pettersson

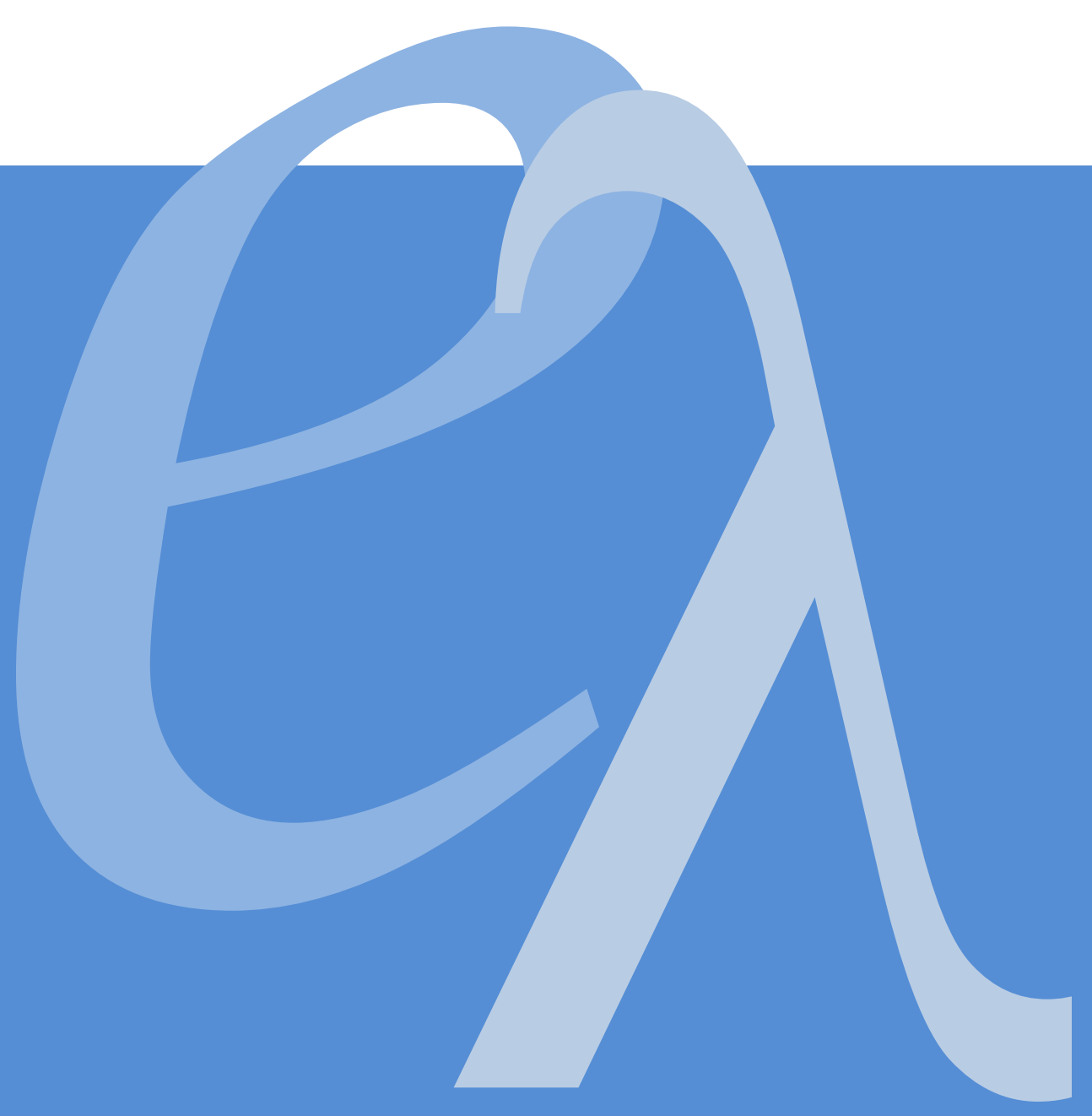




\begin{abstract}
As is well known, the rule of the philosophers is what ultimately completes the political project in Plato's Republic. Only if the philosophers accept to rule, may the city see the light of day. Yet, as is equally well known, the philosophers are reluctant to rule. But ruling is what they are designed to do. Their entire education was constructed to prepare them for this task. And therefore, as Plato's repeatedly puts it, they will need to be compelled. How? As this paper sets out to argue, it is what Plato calls the noble lie that does the job. Established in the philosophers' souls during their childhood, and tested like "gold in the fire", it is only the city-love established by the noble lie that can counteract their otherworldly desire for truth and knowledge. Designed to imbue their souls with a sense of responsibility and care, the noble can outweigh their political reluctance, and turn their eyes back to the city.
\end{abstract}

Keywords: Plato, Republic, noble lie. 


\section{Introduction}

The problems caused by the philosophers' reluctance to engage in the political affairs of the city outlined in Plato's Republic are well documented. ${ }^{1}$ In consequence of their higher education, making the philosophers believe "that while still living they have been transported to the Islands of the Blessed" (519c5-6), the philosophers will be "unwilling to occupy themselves with human affairs" (517c8-9). ${ }^{2}$ The traditional take on this is however to argue that it is unproblematic to reconcile the philosophers' desire for truth and knowledge with their political engagement. ${ }^{3}$ In what follows I shall begin by outlining the details of the problems that this point of view mounts, continue by evaluating the tree most influential alternatives, and pursue by arguing that it is only the particularly strong sense of care and city-love established by the noble lie that, all things considered, can counteract the philosopher's reluctance to engage in the political affairs of their city.

\section{Political Reluctance}

As it has traditionally been argued, Plato's description of the philosophers' unwillingness to engage in politics must be understood in the light of their disposition as lovers of wisdom. ${ }^{4}$ Having seen the forms, it is argued, the philosophers have an inherent wish to imitate (drawing on 500b-d) and express their visions (drawing on the Symposium). And a just city is the perfect, if not the only, place to realize this wish. Ruling a just city, it is claimed, does not only make it possible for the philosophers to embody what they desire in well-ordered and harmonious deeds, but it does also allow them to express their vision of the truth in action, and, in effect, make the good and the beautiful see the light of day. ${ }^{5}$

One passage that is often taken as evidence for this point of view is $520 \mathrm{~d}$. In the context of discussing whether or not it will be an unjust act to force the philosophers to descend and make them live a worse life, when they can live a better (519d), Socrates asks Glaucon if he thinks that the philosophers will resist.

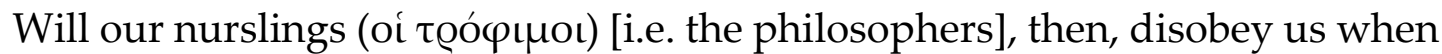
we tell them this, and will they refuse to share in the labours of state (520d6-7)?

\footnotetext{
${ }^{1}$ The various aspects of this issue are, for example, spelled out by Brown (2000), Sedley (2007), Weiss (2007), Woolf (2009), Schofield (2006), Schofield (2007) and Smith (2010). See also below.

2 If not otherwise stated all translations are based on Grube and Reeve in Cooper (1997). The Greek is from Burnet's edition (1903).

${ }^{3}$ As in Irwin (1995, 313ff) or Kraut (1991). For critical discussion, see Sedley (2007, 276), Weiss (2007, 108ff), Brown (2000, 3-6) and Brown (2003).

${ }^{4}$ See, e.g., Kraut (1999), Irwin (1977, 237) or Irwin (1995, 298-317).

${ }^{5}$ For discussion, see Brown $(2000,5)$, Woolf $(2009,17 f)$ and Smith $(2010,97 f)$. Sedley $(2007,276)$ dismisses this kind of interpretation in one sentence.
} 
And Glaucon answers:

Impossible [...] for we shall be imposing just commands on men who are just. (520e1)

Taken in isolation, this passage seems to imply that it is in the true interest of the philosophers to do what is just, and that ruling the city is precisely such a just thing to do. The philosophers will know that their leadership is the only just leadership and they will take office willingly.

If we take a closer look at the context of this passage, the philosopher's willingness to rule will however immediately lose its flare. First of all, Glaucon qualifies his statement in the same breath as it is articulated. Surely, he says, the philosophers will agree to share the labours of the state, but they will not consider this to be something they want to do. Instead, they will consider this task to be something they are compelled to do. Like the other necessities of human life, as Socrates will come to explain much later (at 581d-e), the philosophers will consider ruling to be something necessary, and not something fine. The whole cue goes like this:

Impossible [...] for we shall be imposing just commands on men who are just. Each of them will certainly go to rule as to something necessary ( $\alpha v \alpha \gamma \kappa \alpha \tilde{i}$ s), however, which is exactly the opposite of what's done by those who now rule in each city. (520e1-3)

In contrast to a city in which the rulers want to rule, the Kallipolis will have no eager rulers. Any such desire will be considered base. "Can you name any other type or ideal of life", Socrates soon asks, "that looks with scorn on political office except the life of true philosophers?" (521b1-3). "No, by Zeus", Glaucon answers (521b3). The philosophers of the Kallipolis will not consider ruling something fine, and one fundamental reason for why this is the case is given at 519c.

"Well, then," said I [Socrates], "is not this also likely and a necessary consequence of what has been said, that neither could men who are uneducated and inexperienced in truth ever adequately preside over a city, nor could those who have been allowed to spend their whole lives being educated [i.e. the philosophers], the one because they have no single aim and purpose in life to which all their actions, public and private, must be directed, and the others,

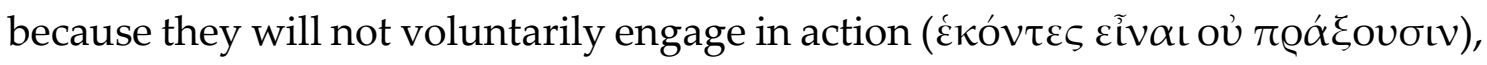
believing that while still living they have been transported to the Islands of the Blessed." (519b7-c6) 
The latter of the two characters types here alluded to, that is, the well-educated philosophers, do apparently think that their visions of truth have already transported them to the Islands of the Blessed. Having been released from the weights of what is below, Socrates explains, and having been turned towards truth, they will be freed (519a-b). And they will have no desire to turn back (cf. 516d and 517c).

Come then [...] and join me in this further thought, and do not be surprised that those who have attained to this height are not willing to occupy themselves

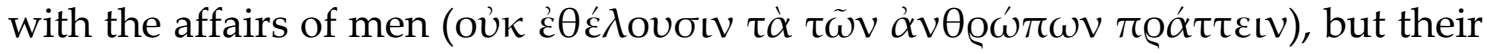
souls ever feel the upward urge and the yearning for that sojourn above. (517c7d2)

Believing that their life is the best there can be, the philosophers will not be willing to engage in the dull affairs of human politics. Recalling their former lives back in the cave, Socrates goes on, this sentiment will also be enhanced. They will remember their old captivated comrades and they will consider themselves blessed. Indeed, Socrates tells us, they would do anything rather than return to the opinions that dominated the life they have now escaped.

"Yes", he [Glaucon] said, "I think that he [the philosopher] would choose to endure anything rather than such a life." (516e1-2)

The unwillingness of the philosophers is also reinforced as the passage continues. Their reluctance to engage in political affairs is in fact not taken to be an undesirable effect of their philosophical disposition at all. This is rather taken to be a sign of a proper attitude (520d). Repeating a claim Socrates initially made around $347 \mathrm{~b}-\mathrm{d}$, he says that "the truth is that the city in which those who are to rule are least eager to hold office must be best" (520d1-3).

The philosopher's unwillingness to rule is furthermore also repeatedly emphasized

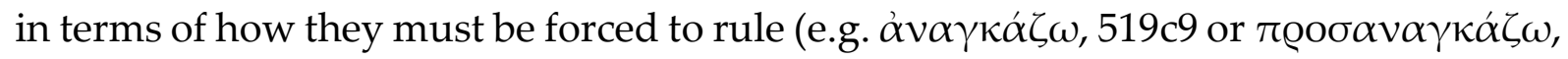
520a8). Eric Brown finds seven passages that explicitly suggest that such a forcing is required (500d, 519e, 520a, 520e, 521b, 539e and 540b). ${ }^{6}$ Allow me to quote one telling passage that captures the context.

"It is the duty of us, the founders, then," said I [Socrates], "to compel the best natures to attain the knowledge which we pronounced the greatest, and to win to the vision of the good, to scale that ascent, and when they have reached the

\footnotetext{
${ }^{6}$ Sedley $(2007,280)$ wants to add $347 b-d$ to the list. Smith $(2010,99$, n.8) $473 d$.
} 
heights and taken an adequate view, we must not allow what is now permitted." "What is that?" [Glaucon asks.] "That they should linger there," I said, "and refuse ( $\mu$ i $\dot{\varepsilon} \theta \dot{\varepsilon} \lambda \varepsilon เ v)$ to go down again among those bondsmen and share their labours and honours, whether they are of lesser or of greater worth." [...] "Observe, then, Glaucon," said I, "that we shall not be wronging, either, the philosophers who arise among us, but that we can justify our action when we

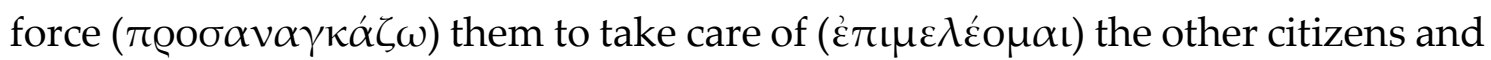
guard ( $\varphi v \lambda \alpha ́ \sigma \sigma \omega)$ them". (519c8-d7 and 520a6-9)

Politics is neither something fine (540b) nor does it make up a life that is equal or even in the proximity of the contemplative life of philosophical activity (519d). Whatever a life of leadership may involve, Socrates remarks, its more or less important preoccupations and rewards will not be something that the philosophers will desire; they will be reluctant. But, as Socrates accordingly also argues, their reluctance will not be sanctioned. It will not be accepted that they should linger on the Islands of the Blessed. Instead, Socrates repeatedly insists, they must return to the cave and "take care of the other citizens and guard them" (520a7-9).

Granted the textual evidence, it is clear that the philosophers have a strong reluctance towards political affairs, and that they will need to be forced to pursue the path of politics. There is, however, many ways to understand this. Most natural perhaps, and certainly quite common, is to appeal to the rational disposition of the philosophers. In what follows I shall begin by trying out three of the most influential arguments to this point, and eventually spell out my own take on the matter against this background.

\section{The Dictates of Prudential Reason}

According to David Sedley, Plato clearly articulates an account of how to force the philosophers to engage in politics that appeals to their rational disposition. In reminding us of the passage in book one where Socrates discusses why the best must rule, Sedley also offers us a lens through which the necessity of philosophical rule might be easier to see. ${ }^{7}$

In the passage Sedley refers to, around 345e-347e, Socrates argues that the usual rewards for governing either comes as money or as honour. Rewards are also necessary, Socrates explains, for no one rules for the sake of ruling. Just as a professional house-builder builds houses for those that are to live in them, the rulers rule for the sake of their subjects. Ruling is always for the benefit of the one being ruled and never for the benefit of the one who rules (346e). Whenever someone desires to

\footnotetext{
${ }^{7}$ Sedley $(2007,273)$.
} 
rule it is not the ruling itself they are after, but its rewards or consequences. And some kind of payment is therefore also reasonably necessary. Just as in the case of the housebuilder, it seems reasonable that the rulers get something for their efforts.

In the case of the best kind of men, however, neither money nor honour will do, Socrates explains. For the best of men are not willing to accept any payment openly

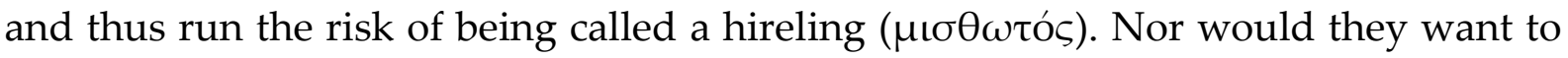
take it in secret and risk to be called a thief ( $\kappa \lambda \varepsilon \dot{\varepsilon} \tau \tau \eta \varsigma)$. Rule for honour is not an alternative either, Socrates continues, for the best type of men do not desire such (347bc). Instead, Socrates suggest, they must be motivated in some other way. They need to be forced. And the device Socrates thus suggests, as Sedley points out, is a punishment. They will realize, Socrates explains, that if they do not rule themselves, they will be ruled by someone else; and the worst of all punishments, Socrates continues (347c), is to be ruled by someone worse (זovๆ@ós).

Now, this idea Sedley calls the dictates of prudential reason..$^{8}$ It is by means of such a dictate, he argues, that the philosophers eventually shall accept to rule. It is in terms of such a self-regulative principle that we must understand the motivation by means of which the reluctance of the philosophers is overpowered, and by means of which they agree to rule. ${ }^{9}$

As one might argue, however, Sedley's dictates of prudential reason may seem to be somewhat too inclusive. The reason for accepting to rule seems to be based on an argument and a rationale that any prudential or sensible person would accept. Since it is a general and rational principle, the dictates of prudential reason can at least not be restricted to the reasoning of the philosophers of the Kallipolis. It is supposedly a dictate that should also apply to those gentle souls that, despite their environment, grow up in other cities and develop a philosophical disposition (520a-b). But in their case, as Socrates insists, there is no requirement to rule at all. They have no debt to their city, Socrates explains, and in contrast to the philosophers of the Kallipolis, they have no obligation to take government and rule.

Given that these exo-philosophers (if I may) have the same intellectual capacity as the philosopher of the Kallipolis, however, the fact that they are not subject to obligatory ruling might seem quite strange, that is, given the rationale of Sedley's prudential dictate. If the force by means of which the philosophers of the Kallipolis are made to rule is the fear of being ruled by the worse, this principle should also apply to those blessed souls that pop up elsewhere. Yet, apparently Socrates does not seem to

\footnotetext{
${ }^{8}$ Sedley $(2007,281)$.

${ }^{9}$ Woolf (2009) has a similar argument.
} 
think that that would be the case. And the dictates of prudential reason do not seem to be a sufficient explanation of how the philosophers are forced to rule. Something more seems to be required.

There is also another objection that might further challenge Sedley's account, for there is, in fact, nothing in the prudential dictate itself that would hinder the philosophers to escape. Yes, there is a law saying that the philosophers of the Kallipolis will not be allowed to run away (520b), but the prudential rationale itself does not establish this law. So, given that the philosophers neither love money nor honour, and that the only rewards they thus would have to look forward to would be the punishment of being ruled by the worse, one reasonable alternative, besides the acceptance of rule, and certainly reinforced by the philosopher's unworldly desire, would of course be to run away. They could choose not to be ruled at all. Such freeriders, as they are often referred to, would thus remain on the Islands of the Blessed. They would be where they most of all desire to be, and they would certainly not be subject to the rule of anyone worse.

Socrates does, however, insist that no such free-riders are allowed in the Kallipolis $(520 \mathrm{~b}-\mathrm{c})$. Yet, since the dictates of the prudential reason would not itself be able to persuade them to stay, the prudential reason does not seem to be a viable principle in this context. In order to make the philosophers stay, and eventually engage in the political affairs of their city, it seems to be necessary to invoke some other kind of principle than the principle of not wanting to be ruled by the worse.

\section{The Rule of Law}

Eric Brown has suggested that it is possible to argue that it is instead a law that Socrates takes to do the job. Drawing especially on 519e and 520a-d, Brown suggests that the force that will make the philosophers engage in politics is a legislated principle. According to Brown the law may be summarized as such: Those who have been educated by the city as philosophers will rule the city. ${ }^{10}$ This law, Brown goes on, is, however, not by itself sufficient. But it will, in combination with a certain conception of justice, do the trick. Understanding justice as a matter of obligatory law-fallowing, he continues, we can also understand how the philosophers are forced to rule. However reluctant they might be, Brown argues, the philosophers are just. And in being just they will

\footnotetext{
${ }^{10}$ Brown $(2000,9)$.
} 
obey the law. Since the law also tells them that they are required to rule, they will, in effect, also obey. ${ }^{11}$

Now, the first aspect of Brown's argument, introducing the law, he draws from 519e-520a. Socrates does here certainly also refer to a law when he explains how and why no free-riders would be allowed in the Kallipolis.

You have again forgotten, my friend [...] that the law (vó $\mu$ os) is not concerned with the special happiness of any class in the state, but is trying to produce this

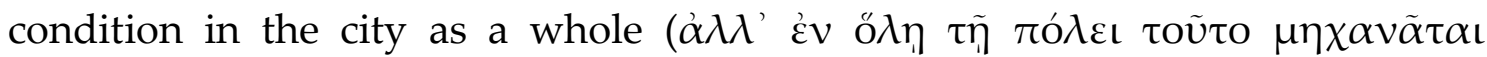
$\dot{\varepsilon} \gamma \gamma \varepsilon v \varepsilon \dot{\varepsilon} \sigma \theta \alpha \mathrm{l})$, harmonizing and adapting the citizens to one another by persuasion $(\pi \varepsilon \iota \theta \omega)$ and compulsion ( $\dot{\alpha} v \alpha \dot{\gamma} \kappa \eta)$, and requiring them to impart to one another any benefit which they are able to bestow upon the community, and that it itself creates such men in the state, not that it may allow each to take what course pleases him, but with a view to using them for the binding together of the

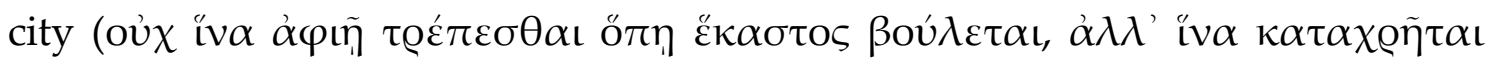

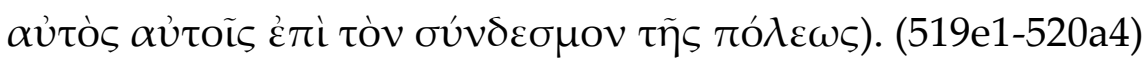

As an answer to Glaucon's complaint that the philosophers will be less well off if they are forced to rule, Socrates invokes the law. Repeating the answer to Adeimantus' objection at the beginning of book four regarding the happiness of the rulers (419a), Socrates turns to Glaucon and says that it is not for the sake of one class of the city that we have laws, but for sake of the entire community (519e). The law, Socrates explains, creates $(\dot{\varepsilon} \mu \pi \mathrm{r} \dot{\varepsilon} \omega)$ philosophers in the city not so that they can do whatever they want, but rather so that they may make a bound of union ( $\sigma \dot{v} v \delta \varepsilon \sigma \mu \rho \varsigma)$ of the city (520a). The law is there to unite the city, and the production of philosophers is a fundamental aspect of that task. The philosophers are educated to be rulers, and thus educated they have no legal right to escape.

In view of the philosophers' reluctance, Brown also suggests that it is this law that does the trick. Having a law that says that the philosophers are required to rule will make them rule. Insofar as the philosophers have received their education in the city, the law will also work, Brown argues, because the philosophers are law abiding subjects. They have a sense of justice, he suggest, that will make them acknowledge the laws and obey them.

Now, this second element of Brown's argument is (admittedly) less obvious in the text. ${ }^{12}$ Appealing to what Glaucon says at 520e, however, Brown argues that there are

\footnotetext{
${ }^{11}$ Brown $(2000,9)$.

12 Brown $(2000,10)$.
} 
reasons to think that there is a conception of justice in play here that does entail obligatory law-following. As we have seen, what Glaucon says in this passage is that since "we will be giving just orders to just people" (520e) there is no way that the philosophers will not obey the command to rule. Accordingly, Brown also argues that "just people are obligated to obey just commands"13 and in appealing to the notion of justice articulated in the Crito and in "the popular conception of justice in Plato's time" he argues that it is also plausible to think that such a notion of justice in also in play here. ${ }^{14}$

The philosophers, Brown explains, will obey just commands, and since they also acknowledge the justice of the law that obligates them to rule, they will obey it. This they will acknowledge, Brown continues, because they will realize the justice of the demand. Having received their entire education in the city, having being fostered and cared for, they will realize that it is now time for them to pay back. Brown calls this idea the principle of reciprocity. And in addition to obligatory law-fallowing, this principle, he writes, is also supposed to be taken to be a fundamental part of the philosopher's sense of justice. A just person does not only acknowledge the rule of law, he also has a sense of debt and paying back what he owes.

Accordingly, Brown can also argue that it is two combined factors that force the philosophers to engage in politics: (1) a particularly pregnant notion of justice and (2) a law. This law, he insists, is important because would it not have been for it, the philosophers would not have taken office. Their sense of justice, Brown suggests, would not have been sufficient in itself. Justice, he claims, cannot by itself force the philosophers to choose the less happy life of ruling.

Supposedly Brown here thinks about this in terms of ruling being a too demanding task. Due to their sense of justice, implying a sense of debt, the philosophers would perhaps acknowledge that they owe the city something, but they would presumably not have chosen a less happy life in order to pay this debt back. According to Brown, such a choice would not in itself have been an unjust act, and accordingly, their sense of justice alone, Brown argues, would not force them to rule. In combination with the law, however, whose obedience is just, it may. ${ }^{15}$

Now, this last point of Brown's argument has been reasonably challenged. For although he might be right in arguing that Plato is not at all alien to a conception of justice as obligatory law-following, there are good reasons to believe that Plato is here

\footnotetext{
13 Brown (2000, 10).

14 Brown (2000, 10).

15 Brown $(2000,10)$.
} 
working with a much stronger conception of justice than Brown wants to admit. As one could argue, there is in fact no need for the law at all. The philosophers' sense of justice is enough.

\section{A Sense of Justice}

This last point of view is also clearly articulated by Roslyn Weiss. While Brown suggests that justice alone cannot force the philosophers to rule, Weiss insists that it certainly can. "The only reason the philosophers will obey the law", she claims, "is because of the justice $[\ldots]$ argument ${ }^{\prime \prime}{ }^{16}$

The justice argument that Weiss here refers to, is a name of the same passages that Brown invoked to argue for his notion of justice as obligatory law-fallowing, i.e. 520e, in which Glaucon says that the philosophers will agree to share the labours of the state because the demand to do so is a just demand addressed to just people. Drawing on this passage, Weiss also goes on to argue that the philosophers will only listen to such a demand, and obey the law that requires their governance, insofar as they deem it to be a just demand and a just law. So, according to Weiss, the law or principle saying that those who have been educated by the city as philosophers will rule the city will only be acknowledged insofar as its justice is also acknowledged. Furthermore, because the philosophers do feel that they are in debt to the city, she argues, they will also appreciate the justice of such a demand.

According to Weiss, then, the philosophers will not accept to rule because there is a (justice neutral) law saying that they must obey for the sake of justice (saying that one must obey the law), but they will obey this law because they consider this law to be just. ${ }^{17}$ Instead of judging it necessary to invoke a conception of justice as obligatory law-following, as Brown argues, Weiss claims that the conception of justice that we are here dealing with ought rather to be understood in terms of a sense of debt. It is also in these terms that Weiss finds the most reasonable account of the force that will make the philosophers rule. "It is justice in the form of repaying a debt", she claims, "that motivates the philosophers to rule" ${ }^{\prime 18}$ It is not an arbitrary law saying that they must rule, because they are in debt, that motivates the philosophers to go back into the cave,

\footnotetext{
${ }^{16}$ Weiss $(2007,111)$.

17 The law, Weiss writes, fills another function. It is there to make the philosophers feel wanted. "Philosophers", Weiss $(2007,111)$ argues, "have no obligation to rule where they are not wanted. They should no more beg to rule than doctors to heal". Yet, insofar as there is a law saying that the philosophers must rule, their services are certainly wanted and they can rule without begging for it.

${ }^{18}$ Weiss $(2007,112)$.
} 
she argues, but it is rather their own realization that only if they pay back what they owe may their acts be just.

This realization, Weiss continues, also has to do with the philosophers' basic motivations and disposition. Although it is not the just acts as acts that ultimately motivates their enactment, the philosophers realize that just acts need to be performed in order for justice to arise in the soul. "[I]n order to become just", Weiss writes, "one must act justly, and refrain from acting unjustly, acting justly is 'profitable' (445a, 588e, 589d, 591a): it 'produces and preserves' justice in the soul (443e-445b, 588b-591c)". ${ }^{19}$ And this, i.e. the justice in the soul, she argues, the philosophers desire. "It is being just, having the condition of justice in one's soul, that appeals" ${ }^{20}$

Accordingly, Weiss goes on, it is also reasonable to account for the motivation that will make the philosophers accept the demand to rule in terms of their sense of justice. They realize, she argues, that they are justly compelled to rule. ${ }^{21}$ Since the city has given them "the extensive education and nurture that make philosophy possible (520ae)", she explains, the philosophers will also realize that they owe the city something. And, since they also have a desire to be just, and know that just acts have an instrumental value, they will also realize that they must accept the demand to rule. This will pay back their debts. It is this, Weiss argues, that will make the philosophers go back into the cave and rule. It is justice, understood to be a matter of paying back their debt to the city, that will make the philosophers acknowledge the justice of the demand obligating them to rule.

From the point of view of the other citizens and from the point of view of the founders, the order and (in effect) the happiness that the philosophers will bring to the city if they rule, is, in other words, a sufficient reason to force the philosophers to rule. From the point of view of the philosophers, however, this is not a sufficient reason. The welfare of the city, Weiss argues, in not a reason strong enough to make the philosophers leave the Islands of the Blessed and return to the cave. ${ }^{22}$ The philosophers must have a stronger motivation, and this stronger motivation, Weiss explains, is the philosophers' desire to be just and, in effect, to act justly. It is also here that their debt enters the picture. Since the philosophers not only have a strong motivation to be just, but also since they acknowledge the justice of the act of paying back their debt to the city that has produced them, they will be motivated to rule, and they will acknowledge the justice of the demand to do so.

\footnotetext{
${ }^{19}$ Weiss $(2007,112)$.

${ }^{20}$ Weiss $(2007,112)$. Weiss' italics.

${ }^{21}$ Weiss $(2007,110)$.

${ }^{22}$ Weiss $(2007,112)$.
} 
The reading thus construed is tempting. Viewed from a somewhat different perspective, there are, however, a few issues that one might want to take into consideration. And I do think that there ultimately are good reasons to doubt that it is only the philosophers' desire to be just by means of paying back their debt that will make them return to the cave, and pursue the path of political rule. There are three lines of thought that support this doubt.

Firstly, then, as Weiss in some sense also acknowledges, one can doubt any account that argues that the philosophers acknowledge the justice of the demand to rule because of their philosophical insights in general. ${ }^{23}$ Since the philosophers' sense of justice is a part of these general insights, there are thus also reasons to doubt that it is this sense of justice alone that will make them accept the demand to rule. This doubt can be spelled out in terms of how Socrates motivates the demand.

For we will say to them [the philosophers of the city] that it is natural that men

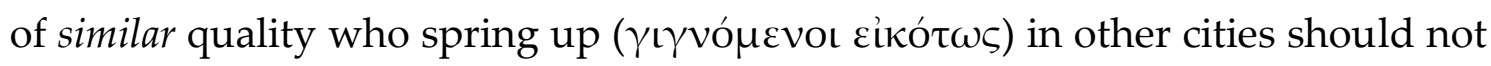
share in the labours there. For they grow up spontaneously from no volition of

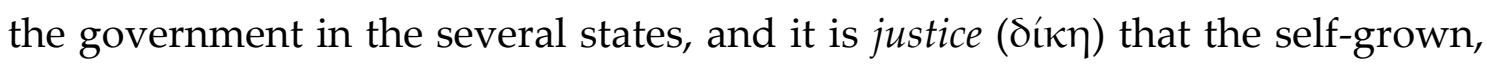
indebted to none for its breeding, should not be eager to pay to anyone the price of its nurture. ${ }^{24}(520 \mathrm{~b} 1-4)$

As we have seen, there is a difference between the philosophers of the city and the philosophers that Socrates explains grow up by themselves, despite the constitution of their city (520b). In contrast to the philosophers of the Kallipolis, the exo-philosophers have no reasons to acknowledge the justice of the demand to rule. Granted that the philosophical insights of the city-philosophers and the philosophical insights of the exo-philosophers are similar, or even the same - including their sense of justice - it can accordingly not be these insights alone that are the reason for why the cityphilosophers, in contrast to the exo-philosophers, would acknowledge the justice of the demand to rule. As it seems reasonable to assume, the exo-philosophers are as just as the city-philosophers, but the exo-philosophers, Socrates explains, have no reasons to think that the demand to rule (their city) is just. And thus the demand to rule cannot be considered to be just because one's philosophical insights make it necessary to think so. Ruling is not something that one considers to be just to do (only) because one is a philosopher. Accordingly we also have reasons to doubt the claim saying that the philosophers will accept to rule (only) because they are philosophers.

\footnotetext{
${ }^{23}$ Cf. Weiss $(2007,109 f)$.

${ }^{24}$ My italics.
} 
There is of course an important difference between the exo-philosophers and the philosophers of the Kallipolis. The exo-philosophers are autodidact while the philosophers of the Kallipolis owe their philosophical insights to the city that has brought them up and educated them. And this, of course, makes all the difference. The exo-philosophers are not indebted to the city. Although they supposedly will realize that it is just for the city-philosophers to pay back their debt to their city, the exophilosophers have no debts to any city. The philosophers of the Kallipolis, however, do. So, accordingly one might also still want to argue that it is the city-philosophers' sense of justice in combination with their debt that will motivate them to rule. There is, however, a second reason to doubt that the philosophers will pursue the path of politics because they are just persons. And this reason does also include the cityphilosophers' debt.

As we have seen, the philosophers are unwilling to occupy themselves with politics and with the human affairs in the cave (cf. 517c8-9), and therefore they need to be forced to do so. There will be a law that will demand this of them, and the philosophers will acknowledge the justice of this law or this demand, because they are just people (520e).

In order to make sense of this, it is plausible to argue along the following lines: The reason for why the philosophers will acknowledge the justice of the demand is because of the philosophical insights that their higher education has granted them. The philosophers have seen true justice and they know what a just act is. They are just people and as just people they do just acts. "And philosophers", Weiss puts it, "qua just men, can be counted on to rule when ruling is what justice demands". ${ }^{25}$ Just acts will preserve and produce the justice of the just person. A just act, Weiss explains, "'produces and preserves' justice in the soul (443e-445b, 588b-591c)". ${ }^{26}$ The philosophers desire to be just, and their just acts will produce and preserve the justice of their souls.

Now, ruling the city, one can argue, is such a just act. It is the act of a just person, and the philosophers will also realize this. They are just persons, and they will realize that ruling the city is a just thing to do, not only because they know that they owe the city the value of their education but also because they realize that their rule would be able to pay back this debt. They will realize that it would be unjust to refuse to rule, and they would accordingly also acknowledge that in ruling they would be performing a just act. Accordingly, since the philosophers have a strong motivation to

\footnotetext{
${ }^{25}$ Weiss $(2007,113)$.

${ }^{26}$ Weiss $(2007,112)$.
} 
be just and thus to do what is just, they would also have a strong motivation to rule. And in virtue of this strong motivation, they would thus also want to rule.

But this is of course the problem, because, as we have seen, the philosophers are describes to be unwilling to occupy themselves with human affairs (517c8-9). "[The philosopher] would choose to endure anything rather than such a life" (516e1-2). They believe that they have better things to do. "For surely, Adeimantus", Socrates explains, "the man whose mind is truly fixed on eternal realities has no leisure to turn his eyes downward upon the petty affairs of men" (500b8-c1). They are not willing (" $\mu \eta$

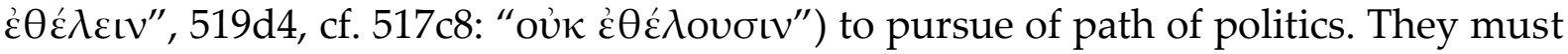
be forced do so, and it is their philosophical insights that are the reasons for why they are reluctant. If the philosophical insights acquired during their time outside the cave alone would have made the philosophers realize that the just thing to do would be to engage in politics, they would supposedly have been described to be willing, if not eager, to do so. But they are not. If they would have realized that the politics of the life in the cave is something worthwhile, they would have considered it to be something fine. But they do not (540b). And accordingly, we also have reasons to doubt that the philosophers will return to the cave because their philosophical insight alone has made them want to engage in politics.

Now, besides these two reasons to doubt that the philosophers will be motivated to pursue the path of politics because they are just persons, there is also a third reason pertaining to the value of the debt involved. For even if we admit the idea that the philosophers will engage in politics because their philosophical insights have made them want to rule, that is, even if we acknowledge that they will be willing to rule because they feel that they owe the city something, this line of thought will nevertheless end up with somewhat unattractive consequences.

According to Weiss, the philosophers will agree to rule because they will realize that if they rule they will be able to pay back their debt to the city. This would be a just act. The philosophers desire to be just, and since being just involves doing just acts, they will accordingly also agree to rule the city. Now, insofar as one is to make sense of this type of argument, however, one must also accept that the philosophers in this situation will consider the value of their rule to be equal to the value of their higher education. Otherwise their rule would not be able to pay back their debts. There must be a balance between the value of their rule and the value of their debt. In virtue of their philosophical insights, one will thus be inclined to argue, the philosophers will know that it is a just thing to pay back what they owe. And, in effect, one must also argue 
that it is in virtue of their philosophical insights that the philosophers value their rule as highly as they value their higher education.

Yet, this is a problematic conclusion, because it implies that one must also argue that Plato writes that the philosophers in this case value political matters just as highly as they value philosophical matters. As we have seen, however, this is not the case. The higher education of the philosophers has not made them value political matters; not even in the Kallipolis. On the contrary, it has taught them the very opposite. For the philosophers, it is only truth and knowledge and the pursuit of such things that have any value. And it is these realizations that have made them reluctant to rule in the first place. It is nothing but their philosophical education that has made them see that political matters have little or no value. As we have seen, there are several passages that make this point.

[T]hey [the best of men] go to it [to rule] not in the expectation of enjoyment nor as to a good thing ( $\dot{\alpha} \gamma \alpha \theta$ ós), but as to something necessary. (347c7-d1)

[The philosopher] would choose to endure anything rather than such a life. (516e1-2)

Can you name any other type or ideal of life that looks with scorn on political office except the life of true philosophers? [...] No, by Zeus. (521b1-3)

[B]ut when the turn comes for each [philosopher], toiling in the service of the state and holding office for the city's sake [i.e. for the Kallipolis' sake], [they will be] regarding the task not as a fine ( $\kappa \alpha \lambda$ ós) thing but as something necessary

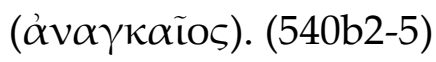

The philosophers regard all types of political power with scorn. They do not think that political power has any value, and supposedly this is a rational conclusion to draw. The philosophers realise this because they are rational beings and because their philosophical education has made them realize which pursuits are really worthwhile. Accordingly we also have further reasons to doubt that the philosophers acknowledge the justice of the demand to rule in virtue of what they have learned from their experiences outside the cave. It cannot be their philosophical insights alone that have made them value their rule as highly as they value their philosophical education. And thus we also have reasons to consider an alternative explanation. There must be some other factor involved here that will make the philosophers think that it is fair to force them to pursue the path of politics. But what, then, could this be? 


\section{To Care for the City}

In order to answer this question, I shall suggest, it might be viable to analyse the reasons for why the philosophers acknowledge the justice of the demand to engage in the politics of the Kallipolis. In order for the philosophers of the city to acknowledge this, it seems, two criteria must be satisfied. The philosopher must (a) think that it is just to pay back their debt to the city, and the philosophers must also (b) think that their rule of the city has an equal value to the education they have been given by the city. Only then can they consider their rule to be a just way to pay back their debts.

The first criterion can, on its own, be said to have rational grounds. Since the philosophers are also rational and reasonable they will think that it is fair to pay back what they owe. Doing so will also make them just persons. As it seems reasonable to believe, the philosophers value their higher education because it has granted them the most blessed of gifts, and thus they feel that they owe the city the value of what they have been given.

The second criterion, however, does not seem to have equally rational grounds. There is at least nothing learnt in their higher education that has made the philosophers value political rule as highly as they value their philosophical education. The reason for this, as we have seen, is that above all other character types the philosophers are the ones who most strongly detest political matters (e.g. 516e or 51b). Ruling can never be considered to be a fine ( $\kappa \alpha \lambda$ ós) preoccupation, not even in the Kallipolis (540b).

So, why then do the philosophers nevertheless value their rule so highly? Granted that we have reasons to doubt that this can be explained in terms of the philosophers' philosophical insights, why do the philosophers, despite the fact that they consider political power to be of little or no worth, nevertheless acknowledge the justice of the demand that they should pursue the path of politics? Or to put it in other words, what is it that the philosophers actually value when they value their political engagement as something that can pay back their debt?

If we take a look at how Socrates spells this out, we will see that it has to do with the preservation and maintenance of the city. The rule of the philosophers pertains to the city's very existence. And the role that the philosophers are to have as rulers is the role of caretakers and guardians. Socrates articulates this in terms of the law.

You have again forgotten, my friend [...] that the law is not concerned with the special happiness of any class in the state, but [the law] is trying to produce this condition in the city as a whole, harmonizing and adapting the citizens to 
one another by persuasion and compulsion, and requiring them to impart to one another any benefit which they are able to bestow upon the community, and that it itself [the law] creates such men in the state [i.e. philosophers], not that it may allow each to take what course pleases him, but with a view to using them for the

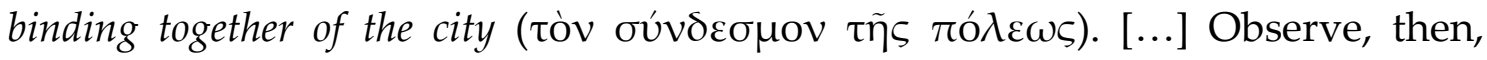
Glaucon [...] that we shall not be wronging, either, the philosophers who arise among us, but that we can justify our action when we force them to take care of the

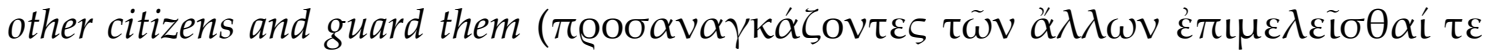

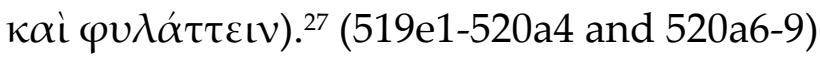

The role of the philosophers as rulers is the role of caretakers, unifiers, preservers and guardians. The philosophers should rule because they can keep the city together better than anyone else. "[Y]ou", Socrates says to the philosophers, "we have engendered for yourselves and [for] the rest of the city to be, as it were, king-bees and leaders in the hive. You have received a better and more complete education than the others" (520b5-c1). This being said directly to the philosopher, and here explicitly articulated in order to justify the demand that they should engage in the politics of the Kallipolis, Socrates is also most likely trying to appeal to something that the philosophers already feel. He is not speaking to them as truth-lovers but as citizens and parts of a greater whole. In addressing the philosophers, Socrates is also most likely trying to appeal to something in the philosophers that will remind them of the intimate bounds they have to the city. ${ }^{28}$

Having just a few lines above made it perfectly clear that the philosophers are made as they are in order to unify the citizens and bind the city together, we also have reasons to believe that Socrates here has something similar in mind. The philosophers are supposed to be aware of the fact that it is only if they will come to rule that the city will persevere. It is therefore also plausible to think that the reason for why the philosophers can be considered to value their rule of the city equal to their higher education is because they care for the city, and because they believe that the perseverance of the city is something valuable and important. Despite the fact that their philosophical education has taught them to consider all political activities with scorn (521b), and despite the fact that their primary interests and desires as philosophers lie far beyond the political life in the cave, the philosophers must care for the city to such a degree that they consider its perseverance to be something valuable. Whatever the philosophical education of the philosophers has ultimately taught them,

\footnotetext{
${ }^{27}$ My italics.

${ }^{28}$ Cf. Schofield (2007).
} 
it has made them unwilling to rule or engage in political activity. And, as we have seen, there are thus also reasons to doubt that what motivates the philosophers to go back into the cave and rule can be accounted for in terms of their rational or philosophical insights alone. This motivation must also come from somewhere else. It must come from their care. But why do the philosophers care for the perseverance of the city? And why do they care for the city at all? Because they have realized that everything worth to pursue exists on a level far beyond the life in the cave? Because they desire knowledge and truth? Or because of those experiences that have made them look on political matters with scorn? Malcolm Schofield has suggested a promising answer. The philosophers care for the city, not because their higher education has taught them so, but because this is a sentiment that has been inserted into the hearts of their souls when they were young and malleable. ${ }^{29}$

\section{The Function of the Noble Lie}

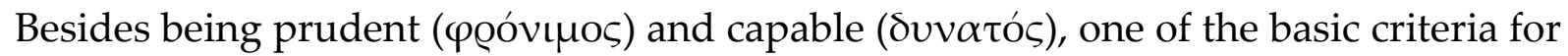
becoming an appropriate ruler of the city is that one shows care for it.

Then, in the first place, mustn't they be knowledgeable and capable, and mustn't they care for $(\kappa \eta \delta \varepsilon \mu \omega ́ v)$ the city? (412c12-13)

The greatest of care, however, one shows to something that one happens to love $(\varphi \iota \lambda \varepsilon \omega)$, Socrates explains. And what one loves the most, he continues, is something that one considers to share one's own interests. When it suffers one suffers oneself, and when oneself suffers it suffers too (412d).

And again, one would be most likely to love that whose interests he supposed to coincide with his own, and thought that when it prospered, he too would prosper and if not, the contrary. (412d4-7)

As Socrates then goes on to explain, it is also for this reason that the rulers of the Kallipolis must be picked out from those that will never diverge from their care and love for the city. Only those that will always do what they find to be the best for the city will do (412e). Most likely referring back to somewhere around 412, Socrates also emphasizes this point at the end of book six.

\footnotetext{
${ }^{29}$ Schofield (2007).
} 
We were saying, if you recollect, that they must approve themselves lovers of the state $(\varphi \iota \lambda$ ó $\pi \mathrm{o} \lambda \iota \varsigma)$ when tested in pleasures and pains, and make it apparent that they do not abandon this fixed faith under stress of labours or fears or any other vicissitude, and that anyone who could not keep that faith must be rejected, while he who always issued from the test pure and intact, like gold tried in the fire, is to be established as ruler. (502e2-503a6)

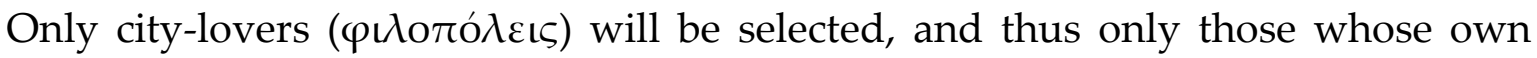
interests are the same as the city's will be selected. This concordance of the interest of the rulers and the interest of the city is supposedly fundamental for the ruler-city relationship.

Back in book three, where Socrates spells this out in some detail, he also dedicates some quite strong wordings to the matter. In terms of how to test the city-love of the rulers-to-be, Socrates goes through what he presumably considers to be the greatest threats to such a love (412c-414a).

Socrates mentions three general factors that might change somebody's mind and take away the established conviction (413b). Someone can (1) steel ( $\kappa \lambda \varepsilon \dot{\tau} \tau \tau \omega)$ it,

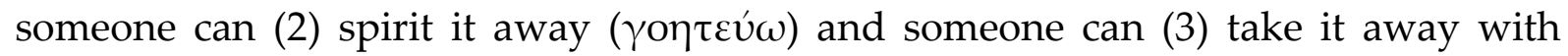
violence $(\beta \iota \alpha ́ \zeta \omega)$.

The first threat, Socrates goes on to explain, has to do either with persuasion or with

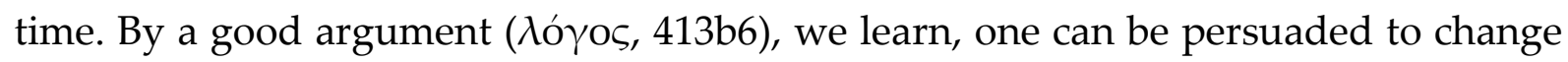
one's mind, and one might also forget. ${ }^{30}$ The second threat is explained in terms of pleasure or fear, and the third as the result of pain or sorrow (413b-c). And only those that have been experimentally exposed to all of these threats and that still persist in their love and care for the city will be selected as appropriate rulers (414a).

Well then, as I was just saying, we must look for those who are the best

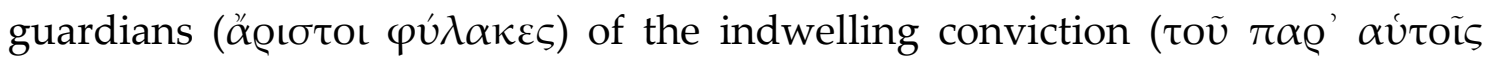
$\delta o ́ \gamma \mu \alpha \tau o \varsigma)$ that what they have to do is what they at any time believe to be best for the state. Then we must observe them from childhood up and propose them tasks in which one would be most likely to forget this principle or be deceived [...] And again we must subject them to toils and pains and competitions in which we have to watch for the same traits [And] must we not institute a third kind of competitive test with regard to sorcery and observe them in that? Just as

\footnotetext{
${ }^{30}$ In the case of forgetfulness, it is time that is the thief (cf. 413b).
} 
men conduct colts to noises and uproar to see if they are liable to take fright, so we must bring these lads while young into fears and again pass them into pleasures, testing them much more carefully than men do gold in the fire, to see if the man remains immune to such witchcraft and preserves his composure throughout. (413c5-e2)

But how, then, is such a strong city-love to be established? Although reluctantly, Socrates answers that they must use a lie. But of what kind, Glaucon asks. It is really nothing new, Socrates answers, but something quite familiar.

[It is nothing] new [...] but a sort of Phoenician tale, something that already has happened in many parts of the world, as the poets say, and have induced men to believe, but that has not happened and perhaps would not be likely to happen in our day and demanding no little persuasion to make it persuasive. $(414 \mathrm{c} 4-7)$

After a few twists and turns, Socrates also spells it out.

Very well, I will speak. And yet I hardly know how to find the audacity or the words to speak and undertake to persuade first the rulers themselves and the soldiers and then the rest of the city, that in good sooth all our training and educating of them were things that they imagined and that happened to them as it were in a dream; but that in reality at that time they were down within the earth being moulded and fostered themselves while their weapons and the rest of their equipment were being fashioned. And when they were quite finished the earth as being their mother delivered them, and now as if their land were their mother and their nurse they ought to take thought for her and defend her against any

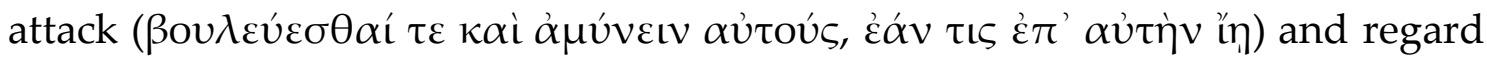
the other citizens as their brothers and children of the self-same earth. ${ }^{31}(414 \mathrm{~d} 1$ e6)

When Glaucon hears this, he replies that he now understands the reasons for why Socrates was so reluctant to articulate this lie $(\psi \varepsilon \tilde{v} \delta o \varsigma, 414 \mathrm{e} 7)$ in the first place. Quite so, Socrates answers, but continues. Besides believing that they are born from the earth, Socrates explains, the citizens of their Kallipolis are also to believe that their

\footnotetext{
${ }^{31}$ My italics.
} 
function in the city, as workers, helpers/soldiers or rulers, will depend on the type of metal that the god inserted into theirs soul when they were created (415a-d). Some are born with bronze, they are to believe, some with silver and some with gold. ${ }^{32}$

Believing that they have been born from the soil of their city, the citizens of the Kallipolis will consider each other to be brothers, Socrates explains. ${ }^{33}$ But as such they must also know that they are valuable ( $\tau \dot{\mu} \mu \mathrm{to}, 415 \mathrm{a} 5)$ in different degrees. It is of the utmost importance, Socrates goes on, that the citizens notice the type of metal with which new children are born. For although it is most common that parents will give birth to children with their own type of metal, this is not always the case. In stressing the importance that the citizens pay heed to their inherent value and that they accordingly do what is appropriate and make their children do likewise, Socrates also ends the story by explaining that there is this prophecy, saying that when a man of iron or bronze will watch over the city, it will fall and be crushed (415a-415c).

\section{Who is the Addressee of the Noble Lie?}

There has been some confusion regarding the addressees of this noble lie. ${ }^{34}$ Since this is a decisive point in the argument I am proposing, it seems adequate to take a closer look at this before I proceed. There are two crucial passages (414b-c and $414 \mathrm{~d}$ ).

The first passage comes just before Socrates spells out the content of the noble lie, and is articulated in terms of how to make rulers that would survive the love-tests mentioned above.

How, then, $[\ldots]$ might we contrive one of those necessary lies of which we were just now speaking, so as by one noble lie to persuade first of all the rulers

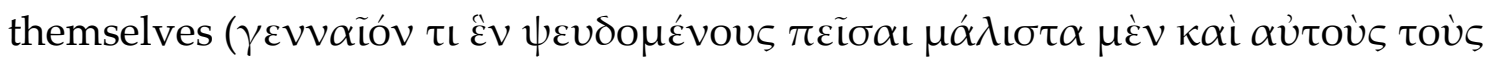
ă $\mathrm{Q} \mathrm{O} \tau \tau \alpha \varsigma)$, but if not that, the rest of the city? (414b8-c2)

This passage refers back to 382c and 389b, where Socrates discusses the fact that a lie may sometimes be used as a medical drug ( $\varphi \alpha \dot{Q} \mu \alpha \kappa o v)$. What I want to stress by

\footnotetext{
${ }^{32}$ The metal that is supposed to permeate the souls of the working-class, a class exemplified by farmers and other

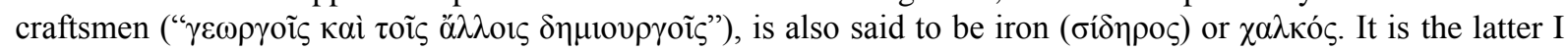
here refer to as bronze, a word that could also be used to refer to copper or even metal in general according to LSJ..

33 “"'As really being', or 'as if they were'?", Schofield $(2006,285)$ asks, "Within the framework of the story the earth, i.e. their native soil, figures as mother (not 'mother, as it were'). But since it would be hard to know what literally believing that might be like, the alternatives dissolve into one".

${ }^{34}$ Both Ferrari $(1989,120)$ and Reeve $(1988,210)$ argue that it is the guardians that are to tell the lie. Annas has some doubts (1981, 107). Cf. also Annas $(1978,443)$. Popper $(1966,139)$ and Schofield (2007) are clear in arguing that the rulers are to believe it.
} 
quoting this passage is however not the fact that Socrates in certain circumstances seems to think that lies may have useful functions, but rather that there is here little doubt as to who the addressee of the lie is. The noble lie is primarily supposed to be

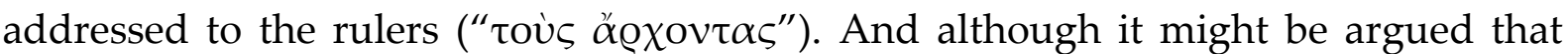
Socrates does here express some doubts that this will work at all, the lie's primary target is again specified a few lies below.

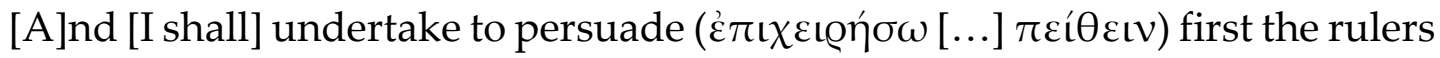

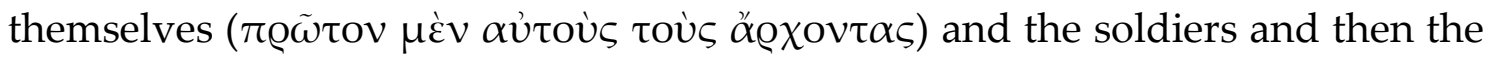
rest of the city. $(414 \mathrm{~d} 2-4)$

In this quote there is clearly no hesitation regarding who Socrates is trying to persuade.

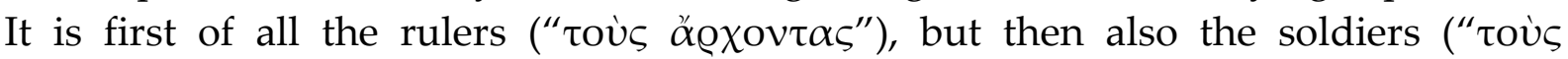

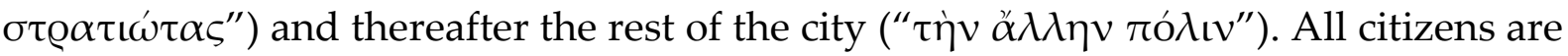
apparently to be persuaded. There is little doubt that anyone is excluded. ${ }^{35}$

\section{How Does the Noble Lie Persuade?}

Granted the importance of the patriotic care that the noble lie is supposed to insert into the soul of its subjects (cf. 412c and 415d), it is of course also of central importance to understand how it is supposed to be believable at all. Indeed, both Socrates and Glaucon express their concern about this matter. Not only is Socrates' introduction of the noble lie full of doubt and hesitation. Socrates also stresses the fact that it will need much persuasion to be persuasive (414c). Glaucon also reflects this doubt. The first generation that will be exposed to the lie will probably not believe it at all, Glaucon says, but, eventually, their sons and their grandsons presumably will.

No, not these themselves [but] their sons and successors and the rest of mankind who come after [will] (415d1-2)

Socrates answers by elaborating Glaucon's point.

\footnotetext{
${ }^{35}$ Compared to the lowest class of the city, however, the doubt is even smaller with regard to the rulers and soldiers. Although implausible, drawing on 415d-e, one could in fact argue that if any class is to be excluded here it is the lowest class. For as Socrates passes on from the story of the noble lie to discuss the lives of the rulers and soldiers he only refers to them as being earth-born, and he somehow seems to neglect the rest of the city: "And let's now arm our earthborn and lead them forth with their rulers in charge. And as they march, let them look for the best place in the city to have their camp, a site from which they can most easily control those within, if anyone is unwilling to obey the laws, or repel any outside enemy who comes like a wolf upon the flock" (415d7-e3).
} 
Well, even that would have a good effect making them more inclined to care

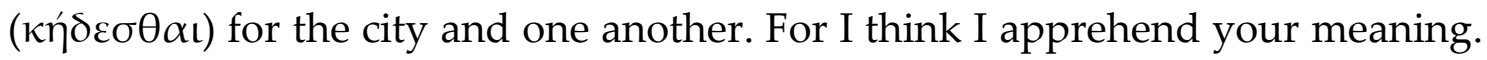

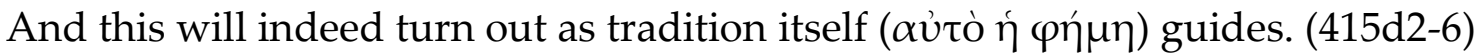

Socrates does not here in so many words spell out how this tradition is supposed to

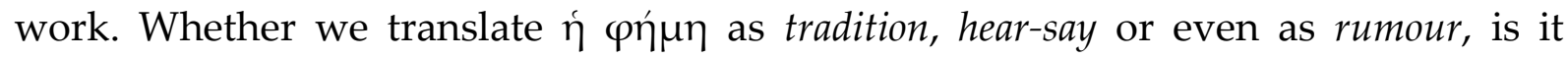
nevertheless quite safe to think that the noble lie is supposed to be persuasive by being a part of the cultural fabric in which new generations are brought up. Although Socrates does not elaborate the matter in this immediate context, he is certainly not silent elsewhere.

As Schofield has also pointed out, it is not at all impossible to locate an account in other parts of the dialogue. ${ }^{36}$ Indeed, the second part of book two and most of book three is dedicated to the matter. In these books, Socrates also goes into some detail regarding how tradition is passed on and how new generations are supposed to be brought up.

Now, in books two and three, the job of transmitter of tradition can basically be said to be the job of the poets and mythmakers $(377 \mathrm{~d}, 377 \mathrm{~b}-\mathrm{d}, 378 \mathrm{~d}-\mathrm{e}$ and $378 \mathrm{e}-379 \mathrm{a}) .{ }^{37}$ And although it is quite clear that Socrates is also speaking about the stories told by the general public, e.g. by those who nurse the children, Socrates argues that if we look at the greater (" $\left.\mu \varepsilon i \zeta o v \varsigma^{\prime \prime}\right)$ products of the poets and mythmakers we shall also be able to

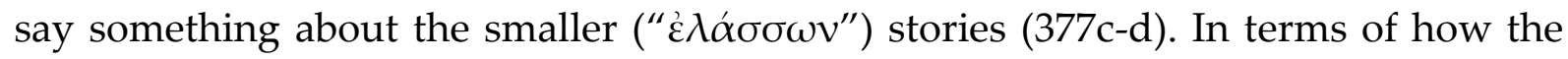
citizens of the Kallipolis are to be brought up, Socrates also explains that the beginning is most important.

Do you not know, then, that the beginning in every task is the chief thing, especially for anyone that is young and malleable? For it is then that the person is best moulded and takes the impression that one wishes to stamp upon it. ${ }^{38}$ (377a12-b3)

[For] whatever opinions are taken into the mind at that age are apt to prove

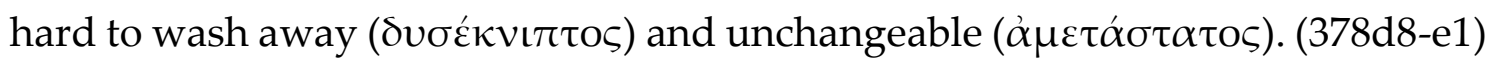

\footnotetext{
${ }^{36}$ Schofield $(2007,153)$.

37 "This is a job for poets", Schofield $(2007,154)$ writes, "not philosophers - presumably because it is the poet, not the philosopher, who is skilled in exploring cultural tradition to produce images and narratives with the requisite resonance and power and who is experienced in moulding people's souls by such means". Regarding the addressee of the poets, see Lorenz (2006, 60 \& 61, n.5).

${ }^{38} \mathrm{Cf}$. also $463 \mathrm{~d}, 500 \mathrm{~d}$ and $522 \mathrm{a}$.
} 
For this reason, then, Socrates goes on, we must also pay careful attention to the stories by means of which the children are brought up (377b). Those stories that are good, Socrates explains, shall be approved, and the others rejected.

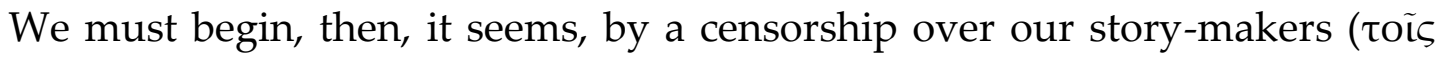
$\mu v \theta о \pi о г о \tilde{\varsigma})$, and what they do well we must pass and what not, reject. And the stories on the accepted list we will induce nurses and mothers to tell to the children and so shape their souls by these stories far rather than their bodies by their hands. (377b11-c5)

The stories that Socrates is here talking about are also specified in this context. They are not only the smaller ones, but they are also the greater ones.

Those [are the stories] that Hesiod and Homer and the other poets related.

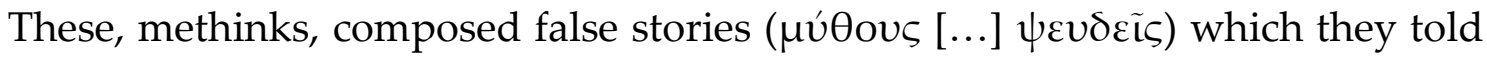
and still tell to mankind. (377d4-6)

In the Kallipolis, however, most of the products of these poets will not be allowed. Judging from this last quote alone it might seem to be the falsehood of the stories that is the reason to reject them. As Socrates a few lines above has made perfectly clear, however, there are two kinds of accounts or narratives ( $\lambda$ ó $\mathrm{ol}, 376 \mathrm{e})$ in play here. There are false $(\psi \varepsilon \tilde{v} \delta \circ \varsigma)$ ones and there are true ( $\dot{\alpha} \lambda \eta \theta \eta \dot{\eta} \varsigma)$ ones (376e). As it comes to the stories told to the children, they are all false on the whole, although they may have some truth in them as well.

Don't you understand [...] that we begin by telling children stories ( $\pi \varrho \tilde{\omega} \tau o v$

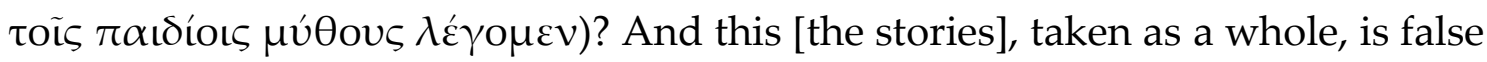
( $\psi \varepsilon \tilde{v} \delta$ os), but there is truth in it also. (377a4-6)

All of the stories described to be part of the basic education of the city, including the accepted ones, are, on the whole, lies. The stories may perhaps contain some fragments of truth, but generally speaking they are lies. It is in any case not the falsehood of these stories that will exclude them from the approved list, but rather their contents and their moral value. And the judges of that are the founders themselves.

Adeimantus, we are not poets, you and I at present, but founders of a state. And to founders it pertains to know the patterns on which poets must compose their stories and from which their poems must not be allowed to deviate; but the founders are not required themselves to compose stories ( $\mu \tilde{v} \theta \mathrm{or})$. (378e7-379a4) 
The job of making up the accepted stories is the job of the poet. The myths are poetry. Although the founders are to sketch up the appropriate framework, the job of working out the actual stories does still pertain to the poets.

Most of the time Socrates and his friends are also primarily occupied with reasoning about the moral value of already existing stories. They try to pick out the good ones and they discuss why some of the stories are to be excluded. With regard to the contents of the stories, they evaluate what kinds of convictions they establish in the souls of the children and based on that they pick out those who install important habits and convictions. Early in book seven Socrates summarizes the point.

It [the musical education] educated the guardians ( $\pi \alpha \iota \delta \varepsilon v ́ o v \sigma \alpha$ toù $\varphi v ́ \lambda \alpha \kappa \alpha \varsigma)$ through habits $(\varepsilon \dot{\varepsilon} \theta \sigma \mathrm{l})$. Its harmonies gave them a certain

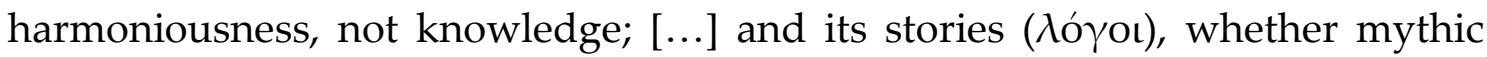
( $\mu \nu \theta \omega \delta \eta \varsigma)$ or nearer the truth ( $\dot{\alpha} \lambda \eta \theta \iota v \omega \tau \varepsilon \varepsilon o \iota)$, cultivated other habits ( $\left.\varepsilon^{\prime} \theta \eta\right)$ akin to these. ${ }^{39}(522 \mathrm{a} 4-8)$

As it comes to one particularly important conviction, however, Socrates does go into some detail. In the case of the noble lie, Socrates apparently thinks that he must be quite specific. For out of the elements of a pair of fairly well-known myths he invents a new story ( $\mu \tilde{v} \theta o \varsigma)$, calls it Phoenician (414c) and, as it seems reasonable to believe, adds it to the censured canon of the Kallipolis. ${ }^{40}$

\section{The Context of the Noble Lie}

In view of how Socrates in the contexts of books two and three spells out the general framework of the musical education of the Kallipolis, it is also possible to understand what Socrates may have meant by the fact that his Phoenician myth was to be established in the Kallipolis by means of tradition or hear-say. As Schofield has

\footnotetext{
${ }^{39}$ Cf. Moss $(2008,57)$.

${ }^{40}$ The noble lie is basically made up of two elements. The first element is the birth from the earth, and the second the metals in the souls. They are, however, clearly supposed to make up one single whole (cf. 415a). The first element, as noted by Adam $(1902,195)$ and Guthrie $(1975,462)$ is presumably an allusion to the story of the foundation of Thebes. Cadmus, we learn, was a Phoenician who once funded this city by means of sowing dragon teeth from which a race of giants was grown. As Page $(1991,22)$ points out, however, this race did eventually fall in a great civil war. This might be a reason for why Socrates is not satisfied with a simple autochthonous brotherhood, but also introduces the other element into his story, i.e. the metallic flavoured souls. This is an allusion to Hesiod, as Socrates also makes perfectly clear (at 574a), and it is perhaps a way to suggest that the city they are out to design shall, by means of this element, not fall prey to the same fate. The first element, of being earth-born, may also, as has been suggested by Page (1991) and Hesk (2000, 160), be an allusion to the money-making part of the soul, and this suggests that Socrates, as we shall also see, is well aware of the fact that the noble lie is primarily designed to persuade the lowest part of the soul. See also Schofield (2006, 256ff).
} 
pointed out, it is certainly also in this context that the noble lie belongs. ${ }^{41}$ For a story that is supposed to persuade by means of tradition and over a span of generations, must, in some way or another, imbue the fabric of the culture. Just like the other stories and myths granted a place in the canonical poetry of the Kallipolis, it seems, the stories about the citizens' earth-born origin and their metal-permeated souls are to become part of the city's everyday life. Although these poetical stories may perhaps only occasionally become the object of recitation at public gatherings, it seems quite safe to think that they are supposed to be told to the children. Just like the other stories of the Kallipolis, the noble lie will be told to the children by their nurses and educators. When Glaucon explains that the noble lie will become more persuasive as the generations progress, it does at least seem likely that it is something along these lines that he had mind (415d). When Socrates in that context also explains that the noble lie shall be persuasive by means of tradition or hear-say it does in any case seem reasonable to assume that he is thinking about tradition in the same terms as he spelled it out in book two and three.

In comparison to the other convictions that the other stories of the Kallipolis' musical education are supposed to establish in the souls of its children, however, Socrates seems to be extra concerned about the noble lie. When it comes down to the patriotism and the care that this lie is supposed to establish, Socrates has also taken some extra measures - at least with regard to the rulers-to-be. As we have seen, it is also for this reason that Socrates prescribes a pair of tests. The patriotism and the care that the noble lie is supposed to establish, must stand firm, Socrates explains, no matter what. In order to be sure that this conviction has been properly formed in the souls of the rulers-to-be, they must be exposed to the most challenging tests. Their feeling of unity and mutual interest with the city must be unchangeable. Their care, and the means by which it is established, must be of a quite remarkable kind. Like true gold in fire, Socrates explains, it must pass all tests. And the ways by means of which this conviction must be entrenched in their souls, must also be so strong and deep that

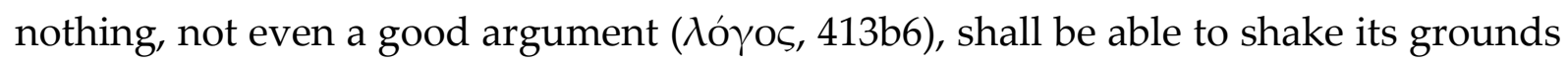
(cf. 413e-414d and 503a).

The power of such a conviction and the force by means of which it apparently is to trump all other experiences and motivations, may remind the attentive reader of the force of such a power that Socrates describes in the Apology. However dangerous the accusations and arguments of Anytus, Meletus and Lycon might have been (18b and 23e), there was another, stronger force in play. Socrates' true accusers and the ones he feared the most were not the ones that brought him to court, but the shadows of

\footnotetext{
${ }^{41}$ Schofield $(2007,153)$.
} 
tradition. It was rumour and hearsay that were his true accusers (cf. 18d). Socrates explains the matter in addressing his audience.

They spoke to you at an age at which you would believe them most readily, some of you in youth and most of you in childhood [and] the most unreasonable thing of all is this, that it is not even possible to know and speak their names [...] $(18 \mathrm{c} 5-\mathrm{d} 1)^{42}$

If Socrates was right, it was certainly also these unmentionable shadows that persuaded the jury and sentenced him to death. ${ }^{43}$ And they did apparently not work by direct argument and rational persuasion, but by the complex and forceful mechanisms of hearsay and tradition. The disadvantageous image of Socrates, that is, the image that ultimately convicted him, became a part of public opinion. It established itself in the souls of the young. While these children grew up, and echoed the stories, the general hostile attitude towards Socrates grew stronger, and eventually killed him.

There is one central passage in the Republic by means of which one can imagine the situation.

[It is] when [...] the multitude are seated together in assemblies or in courtrooms or theatres or camps or any other public gathering of a crowd, and with loud uproar censure some of the things that are said and done and approve others, both in excess, with full-throated clamour and clapping of hands, and thereto the rocks and the region round about re-echoing redouble the din of the censure and the praise. In such case how do you think the young man's heart, as the saying is, is moved within him? What private teaching do you think will hold out and not rather be swept away by the torrent of censure and applause, and borne off on its current, so that he will affirm the same things that they do to be honourable and base, and will do as they do, and be even such as they? (492b58)

Even if Socrates here characterises this situation as he does in order to expose its absurdities, the passage does nevertheless seem to offer a key to understanding how Socrates takes the forces of hear-say and public opinion to work. No private teaching can stand its ground here, he says. For the currents of public opinion will sweep away even the strongest of private teachings. And although Socrates' account of education

\footnotetext{
42 Translation by Fowler (2006).

${ }^{43}$ The word that Socrates here uses to describe his defence against these unmentionable accusers is $\sigma \kappa 1 \alpha \mu \alpha \chi \varepsilon ́ \omega$, meaning just that: to fight against shadows (18d6).
} 
by means of myths and stories is perhaps less spectacular, the force in play seems to be similar. The poetical canon of the Kallipolis is not supposed to educate by means of rational argument, but by means of tradition and hear-say. The selected stories are not only to be told by the designated poets in the theatres and at public gatherings, but also in private, by educators and nurses. ${ }^{44}$

\section{Summary and Conclusion}

The problem of how to get the philosophers to rule turns on the strength of their desire for truth and knowledge. Their higher education has taught them that only this pursuit is worthwhile, and therefore they are "unwilling to occupy themselves with human affairs" (517c8-9). Yet, to return to the city is their very purpose, and therefore, as Plato repeatedly writes, they must be forced. How? Entrenched in the souls of the philosophers by means of tradition or hearsay ( $\varphi \eta \mu \eta, 415 \mathrm{~d} 6)$, the noble lie establishes a particularly strong city-love. "Hard to wash away and unchangeable" (378d8-e1), it will stay the same no matter what. Regardless of what the rulers-to-be will experience when they are exposed to the light of truth, the patriotism established in their childhood will remain (413b). Even if someone tries to steal it by argument or persuasion, spirit it away by pleasure or fear, or take it away with violence, it will persist. Not even their experiences outside the cave will be able to change this. Long after the philosophers has been appointed kings the importance of their patriotism is also repeated (502e2-503a6). And even if they will see, what Schofield describes as, "something incomparably more important than the city, and something far more desirable and good" 45 , the noble lie will eventually turn their eyes back to politics.

\footnotetext{
${ }^{44}$ Cf. Moss (2008, 57f).

${ }^{45}$ Schofield (2007, 162).
} 


\section{Bibliography}

Adam, James, The Republic of Plato, Cambridge: Cambridge University Press, 1902.

Brown, Eric, "Justice and Compulsion for Plato's Philosopher-Rulers", in Ancient Philosophy, No.20, 2000.

----, "Minding the Gap in Plato's 'Republic'", in Philosophical Studies: An international Journal for Philosophy in the Analytical Tradition, Vol.117, No.1/2, 2003.

Burnet, John (ed.), Platonis Opera, Oxford: Oxford University Press, 1903.

Cooper, M, John (ed.), Plato - Complete Works. Indianapolis and Cambridge: Hackett, 1997.

Ferrari, G.R.F, "Plato and Poetry", in The Cambridge History of Literary Criticism, Cambridge: Cambridge University Press, 1989.

Fowler, N., Harold, Plato with an English translation, Vol. I: Euthyphro, Apology, Crito, Phaedo, Phaedrus, The Loeb Classical Library, Cambridge, Massachusetts: Harvard University Press, 2006.

Guthrie, W.K.C, A History of Greek Philosophy, Vol. IV, Cambridge: Cambridge University Press, 1975.

Hesk, Jon, Deception and Democracy in Classical Athens, West Nyack: Cambridge University Press, 2000.

Irwin, Terence, Plato's Ethics, Oxford: Oxford University Press, 1995.

Plato's Moral Theory: The Early and Middle Dialogues, Oxford: Oxford University press, 1977.

Kraut, Richard, "Return to the Cave: Republic 519-521", in Fine, Gail (ed.), Oxford Readings in Philosophy - Plato: Ethics, Politics, Religion, and the Soul, Oxford: Oxford University Press, 1999.

Moss, Jessica, "Appearance and Calculation: Plato's Division of the Soul", in Oxford Studies in Ancient Philosophy, No.34, 2008.

Popper, K.R., The Open Society and Its Enemies, London: Routledge \& Kegan Paul, 1966. 
Page, Carl, "The Truth About Lies in Plato's Republic", in Ancient Philosophy, No.11, 1991.

Reeve, C.D.C., Philosopher-Kings, Princeton: Princeton University Press, 1988.

Schofield, Malcolm, "The Noble Lie", in Ferrari, G.R.F (ed.), The Cambridge Companion to Plato's Republic, Cambridge: Cambridge University Press, 2007. Plato - Political Philosophy, Oxford: Oxford University Press, 2006.

Smith, D, Nicholas, "Return to the cave", in McPherran, J, Mark (ed.), Plato's Republic: A Critical Guide, Cambridge: Cambridge University Press, 2010.

Sedley, David, "Philosophy, the Forms, and the Art of Ruling", in Ferrari, G.R.F (ed.), The Cambridge Companion to Plato's Republic, Cambridge: Cambridge University Press, 2007.

Weiss, Roslyn, "Wise Guys and Smart Alecks in Republic 1 and 2", in Ferrari, G.R.F (ed.), The Cambridge Companion to Plato's Republic, Cambridge: Cambridge University Press, 2007.

Woolf, Raphael, "Truth as a Value in Plato's Republic", in Phronesis, No.54, 2009. 


\section{E- LOGOS}

\section{ELECTRONIC JOURNAL FOR PHILOSOPHY}

Ročník/Year: 2014 (vychází průběžně/ published continuously)

Místo vydání/Place of edition: Praha

ISSN 1211-0442

Vydává/Publisher:

Vysoká škola ekonomická v Praze / University of Economics, Prague

nám. W. Churchilla 4

Czech Republic

13067 Praha 3

IČ: 61384399

Web: http://e-logos.vse.cz

Redakce a technické informace/Editorial staff and technical information:

Miroslav Vacura

vacuram@vse.cz

Redakční rada/Board of editors:

Ladislav Benyovszky (FHS UK Praha, Czech Republic)

Ivan Blecha (FF UP Olomouc, Czech Republic)

Martin Hemelík (VŠP Jihlava, Czech Republic)

Angelo Marocco (Pontifical Athenaeum Regina Apostolorum, Rome, Italy)

Jozef Kelemen (FPF SU Opava, Czech Republic)

Daniel Kroupa (ZU Plzeň, Czech Republic)

Vladimír Kvasnička (FIIT STU Bratislava, Slovak Republic)

Jaroslav Novotný (FHS UK Praha, Czech Republic)

Jakub Novotný (VŠP Jihlava, Czech Republic)

Ján Pavlík (editor-in-chief) (VŠE Praha, Czech Republic)

Karel Pstružina (VŠE Praha, Czech Republic)

Miroslav Vacura (executive editor) (VŠE Praha, Czech Republic) 